\title{
Production of Arugula Under Doses of Bokashi Fermented Compound
}

\author{
Kirk Renato Moraes Soares ${ }^{1}$, Carla Coelho Ferreira ${ }^{1}$, Aurinei da Silva Ramos ${ }^{1}$, Ana Cecília Nina Lobato ${ }^{1}$, \\ Therezinhade Jesus Pinto Fraxe ${ }^{1}$, Henrique dos Santos Pereira ${ }^{1} \&$ Albejamere Pereira de Castro ${ }^{1}$ \\ ${ }^{1}$ Postgraduate Program in Tropical Agronomy, Federal University of Amazonas, Manaus, Brazil \\ Correspondence: Kirk Renato Moraes Soares, Postgraduate Program in Tropical Agronomy, Federal University \\ of Amazonas, Manaus, Brazil. Tel: 55-929-8151-9565. E-mail: kirk_soares@yahoo.com
}

Received: February 19, 2019

Accepted: August 24, 2020

Online Published: September 15, 2020

doi:10.5539/jas.v12n10p181

URL: https://doi.org/10.5539/jas.v12n10p181

\begin{abstract}
Fermented composts are made from animal, plant and or/mineral materials. The fermentation process can be accomplished through the action of microorganisms collected from soils, plant litter and/or baker's yeast. This study aimed to evaluate arugula (Eruca sativa) yields with application of different doses of bokashi-type fermented compost. The experimental design consisted of randomized blocks with five treatments $(0,100,200$, $300,400 \mathrm{~g} \mathrm{~m}^{-2}$ ) and four replications. Fermentation of the compost occurred in ten days, and in this period the compost mass was turned up twice a day during the first three days and daily during the seven next days. The fertilizer was incorporated three days before planting into a $0-5 \mathrm{~cm}$ deep layer. The methods used for data analysis were ANOVA and regression analysis at $5 \%$ probability level. The variables examined were: number of leaves, plant height, dry and fresh weight of roots and shoots. The use of bokashi at the rate of $300 \mathrm{~g} \mathrm{~m}^{-2}$ resulted in better agronomic performance, demonstrating to be a viable alternative for the production of arugula under local edaphoclimatic conditions.
\end{abstract}

Keywords: organic fertilization, agroecology, Eruca sativa, leafy greens, yield

\section{Introduction}

Arugula (Eruca sativa Miller) is a leafy vegetable of the Brassicaceae family. It is an annual, small size plant mostly grown in regions of temperate climate in Brazil, but has also exhibited good productive development in warmer regions of the country (Gusmão et al., 2003). Arugula leaves are rich in vitamin C and minerals, especially calcium $(\mathrm{Ca})$ and iron $(\mathrm{Fe})$, and has a detox effect on the body and an anti-inflammatory effect on human intestines (Trani, Fornasier, \& Lisbão, 1992; Mahmoud \& Taha, 2018).

It is usually cultivated using high-soluble fertilizers, which cause harmful effects to the soil over the years. However, organic matter $(\mathrm{OM})$ is an alternative to chemical fertilization, because it provides long-term beneficial effects to the soil, improving their physical, chemical and biological properties, supplying macro and micro nutrients to the plants, in addition to making the plants less susceptible to diseases (Primavesi, 2002; Condé, D. Oliveira, \& J. Oliveira, 2017; Mahmoud \& Taha, 2018). The use of OM appears as a way to mitigate the high costs involved in conventional cultivation processes in Brasil, a major importer of agricultural inputs, which makes the country hostage to price fluctuations, often quoted in dollars (SBCS, 2010).

Among the OM sources are organic composts, which can be produced by mixing different materials and will be ready for use in 90 to 120 days. When incorporated to the soil, it provides nutrition and an increase of the microorganisms present in soil (Souza \& Resende, 2003; Franco, S. Silva, Emiliano, M. Silva, \& Costa, 2018).

Among organic composts are the fermented ones, which were formerly prepared using oilseed cake and meal. However, over the years, it was observed that it was possible to prepare it with existing materials available in the properties, respecting only the proportion of elements that are source of nitrogen $(\mathrm{N})$, carbon $(\mathrm{C})$ and inoculants, which are spread in layers and later mixed, undergoing an aerobic or anaerobic fermentation process. The inoculants can be found in forest litter and baker's yeast, which can be used together or separately (Souza \& Resende, 2003).

Efficient microorganisms (EM) act on the OM through a degradation process, releasing into the soil organic compounds such as hormones, antibiotics, macro and micro nutrients, which improve the physical, chemical and biological properties of the soil and promote the development of cultivated vegetables (Carvalho, V. Barros, Figueiredo, M. Barros, \& Ferreira, 2018). 
The process to produce fermented composts employs the methodology for preparation of bokashi, a Japanese word for fermented fertilizer. It is a costly production process when it uses oilseed cake and meal. However, costs decrease considerably when the bokashi preparation principles are used with materials available in the producing regions (Magrini, Camatti-Sartori, Finkler, Torves, \& Venturin, 2011).

The study of alternative fertilizer sources is of vital importance to reduce Brazilian dependence on foreign suppliers and provide national producers with access to low-cost production techniques, less harmful to the environment. This study aimed to assess the effect of different doses of the bokashi-type fermented compost on arugula productivity.

\section{Material and methods}

\subsection{Location of the Experiment}

The experiment was carried out at the experimental farm of the Federal University of Amazonas - UFAM, at the geographic coordinates $2^{\circ} 39^{\prime} \mathrm{S}$ and $60^{\circ} 3^{\prime} \mathrm{W}$, and climate defined as Am, tropical, warm and humid, according to Köppen classification, and an altitude of $96 \mathrm{~m}$ at the highest parts. Average annual temperature, rainfall and humidity are 25 to $28{ }^{\circ} \mathrm{C}, 2,100 \mathrm{~mm}$, and 84 to $90 \%$, respectively (Ribeiro et al., 1999).

\subsection{Soil Analysis}

The textural composition indicated a Yellow Latosol soil (EMBRAPA, 2006). The chemical analysis of the soil was carried out with ten samples collected from the experimental area, comprising a total sample of $500 \mathrm{~g}$ (Veloso, Viégas, Oliveira, \& Botelho 2006), which were analyzed at the soil laboratory of UFAM (EMBRAPA, 1997) (Table 1).

Table 1. Chemical analysis of the soil in the experimental area of arugula production with different rates of bokashi fermented compost

\begin{tabular}{|c|c|c|c|c|c|c|c|c|c|c|c|c|}
\hline $\mathrm{pH}$ & $\mathrm{OM}$ & $\mathrm{P}$ & $\mathrm{K}$ & $\mathrm{Ca}$ & $\mathrm{Mg}$ & $\mathrm{Al}$ & $\mathrm{H}+\mathrm{Al}$ & TEB & ECEC & CEC & $\mathrm{BS}$ & M \\
\hline $\mathrm{H}_{2} \mathrm{O}$ & $\mathrm{g} \mathrm{kg}^{-1}$ & \multicolumn{2}{|c|}{-- $\mathrm{mg} \mathrm{dm}^{3}$-- } & $-\cdots$ & ----- & ---- & --- $\mathrm{cm}$ & $\mathrm{m}^{3}-\cdots$ & -------- & --------' & \multicolumn{2}{|c|}{--- \% - - } \\
\hline 4.5 & 2.5 & 17 & 46 & 2.6 & 1.4 & 0.3 & 5.2 & 4.12 & 4.42 & 9.32 & 44.2 & 6.79 \\
\hline
\end{tabular}

Note. $\mathrm{OM}=$ organic matter content $\mathrm{TEB}=$ Total Exchangeable Bases; $\mathrm{ECEC}=$ Effective Cations Exchange Capacity; $\mathrm{CEC}=$ Cations Exchange Capacity (pH 7); BS = Base Saturation; $\mathrm{M}=$ Aluminum saturation.

\subsection{Preparation of Bokashi Fermented Compost}

To prepare the fermented compost, $0.05 \mathrm{~m}^{3}$ of laying-chicken manure (corresponding to two $50-\mathrm{kg}$ bags), $0.1 \mathrm{~m}^{3}$ of soil, $0.1 \mathrm{~m}^{3}$ of chopped straw (Paspalum virgatum $\mathrm{L}$ ), $0.05 \mathrm{~m}^{3}$ of charcoal powder, $5 \mathrm{~kg}$ of wheat bran, $5 \mathrm{~kg}$ of dolomitic limestone, $5 \mathrm{~kg}$ of plant litter, $1 \mathrm{~L}$ of molasses, $100 \mathrm{~g}$ of granulated biological baker's yeast, $5 \mathrm{~kg}$ of rock powder, and water were used (Restrepo, 2014).

In $20 \mathrm{~L}$ of water, the molasses and the baker's yeast were dissolved, and the mixture was homogenized and kept in a container protected from the sun and rain. Five 10-cm layers were formed with the same composition, comprised of the following sublayers: $1^{\text {st }}$-straw, $2^{\text {nd }}$-soil, $3^{\text {rd }}$-laying-chicken manure, $4^{\text {th }}$-wheat bran, $5^{\text {th }}$-charcoal powder, $6^{\text {th }}$-plant litter, and $7^{\text {th }}$-dolomitic limestone. Each lawyer was moistened with a solution of water, molasses and biological yeast.

The fermentation process was accomplished in ten days, and during this period the compost piles were turned up twice a day in the first three days, and daily in the seven subsequent days (Restrepo, 2014). When ready, 300g of the compost were collected and taken to the soil laboratory at UFAM for analysis-Kjeldahl method (Brasil, 2014) (Table 2).

Table 2. Chemical analysis of the bokashi fermented compost applied at different rates in arugula cultivation

\begin{tabular}{|c|c|c|c|c|c|c|c|c|c|c|c|c|}
\hline $\mathrm{pH}$ & $\mathrm{OM}$ & $P$ & K & $\mathrm{Ca}$ & $\mathrm{Mg}$ & $\mathrm{Al}$ & $\mathrm{H}+\mathrm{Al}$ & TEB & ECEC & CEC & BS & M \\
\hline $\mathrm{H}_{2} \mathrm{O}$ & $\mathrm{g} \mathrm{kg}^{-1}$ & \multicolumn{2}{|c|}{--- $\mathrm{mg} \mathrm{dm}{ }^{3}$--- } & ---- & ----- & ---- & $----\mathrm{cl}$ & $\mathrm{m}^{3}$ & ------ & -------- & \multicolumn{2}{|c|}{------- \% ------ } \\
\hline 6.8 & 8.4 & 188 & 280 & 7 & 5 & 0 & 1 & 25 & 25 & 26 & 96.16 & 0 \\
\hline
\end{tabular}

Note. $\mathrm{OM}=$ organic matter content TEB $=$ Total Exchangeable Bases; ECEC $=$ Effective Cations Exchange Capacity; $\mathrm{CEC}=$ Cations Exchange Capacity ( $\mathrm{pH}$ 7); $\mathrm{BS}=$ Base Saturation; $\mathrm{M}=$ Aluminum saturation. 


\subsection{Experiment Implementation}

The experimental design consisted of randomized blocks with five treatments and four replications, each one comprised of the average of ten viable plants. The rates of fermented compost applied on the soil were 0,100 , $200,300,400 \mathrm{~g} \mathrm{~m}^{-2}$, which corresponded to $0,1,2,3,4 \mathrm{tha}^{-1}$, respectively.

The experiment was conducted in open field. Soil tillage consisted of clearing, plowing, harrowing, and building beds with $0.20 \mathrm{~m}$ in height. Three days before planting, the fermented fertilizer was spread manually on the soil. Direct sowing occurred on November 10, 2017, by laying five to seven seeds in 2-cm deep holes. Thinning was conducted seven days after planting and only one plant per hole was kept. The arugula species used was the broadleaf cultivar. Spacing was $0.10 \mathrm{~m}$ between rows and $0.20 \mathrm{~m}$ between plants (Andreani Junior, Rocha, \& Kozusny-Andreani, 2016).

The area was kept weed-free by hand weeding, and no phytosanitary control was performed. Irrigation was made with a hose on the days with no occurrence of rain, given that the experiment was conducted in the period of November and December, which are the months with the highest precipitation indices in the region of the study.

\subsection{Parameters Assessed}

The plants were harvested in a single work's day, 30 days after planting (Menin, Rambo, Frasson, Pereira, \& Santi, 2014). The plants were harvested by hand, by pulling out the entire plant. The following parameters of each of ten plants cultivated in each plot's net area were assessed:

Number of leaves: the leaves with commercial value were counted, i.e., those with no signs of predation or disease. The count began from the basal leaves to the last open leaf (Tosta, Silva, Espinoso, Costa, \& Lima, 2016; Soares, Bardiviesso, Barbosa, \& Barcelos, 2017).

Plants' height: each plant was measured from the ground level to the furthest point of the highest leaf using a millimeter ruler and expressed in centimeters (Tosta et al., 2016; Soares et al., 2017).

Fresh weight: after harvest, the plant was washed under running water and the roots were separated. The entire plants and the roots were weighed using a digital scale. The fresh biomass weight was expressed in g.plant ${ }^{-1}$ (Tosta et al., 2016).

Dry weight: the plants were weighed in a digital scale after being dried to constant weight in a forced-air circulation oven at $65^{\circ} \mathrm{C}$. The weight was expressed in g.plant ${ }^{-1}$ (Soares et al., 2017).

\subsection{Statistical Analysis}

The data were subjected to analysis of variance (ANOVA) and regression analysis at 5\% probability level, using the SISVAR software (Ferreira, 2014).

\section{Results and Discussion}

After an extensive literature search, it could be seen that there are few scientific studies on organic fertilization used in arugula cultivation, which justifies the importance of the present study. Additionally, organic fertilizers improve the physical, chemical and biological properties of soil, resulting in improved plant growth and development. Furthermore, fermented organic fertilizers have the advantage of eliminating possible contaminants due to the high temperatures used in the fermentation process (Ferreira et al., 2018). Therefore, the bokashi organic fertilizer is a viable agroecological alternative because it is easy to produce and apply, in addition to providing better yields (Carvalho et al., 2018).

Because arugula is a leafy vegetable, the variables relating to number of leaves, height and biomass have a role in the commercial value. The evaluation of these parameters in arugula plants with different rates of bokashi revealed that the recommended dose is $300 \mathrm{~g} \mathrm{~m}^{-2}$, corresponding to $3 \mathrm{tha}^{-1}$.

The dose of $300 \mathrm{~g} \mathrm{~m}^{-2}$ of bokashi increased the number of leaves of arugula plants, with an approximate average number of of nine leaves per plant, an increase of $14 \%$ when compared to the plants grown without fertilization (Figure 1). Contrasting results were found by Carvalho et al. (2018), who found that the use of straw and efficient microorganisms did not have an influence on the number of arugula leaves, and also in the study of Soares (2017), where the highest average number of arugula leaves obtained with fertilization was eight. 


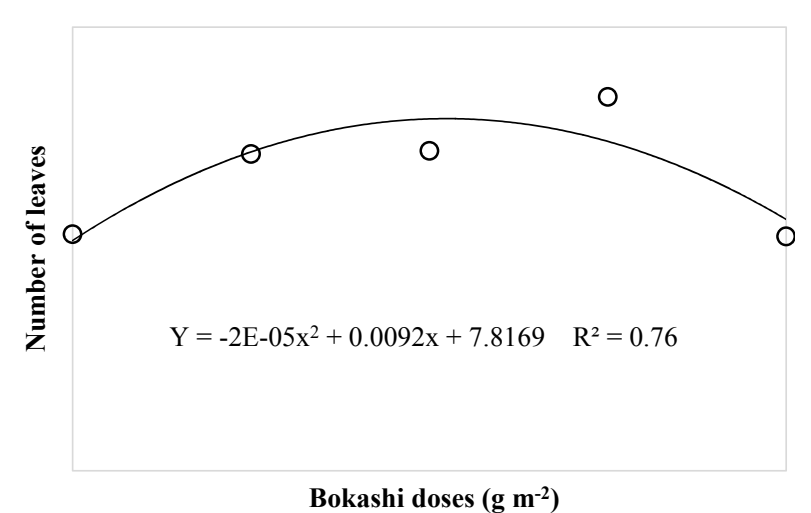

Figure 1. Number of arugula leaves as a result of bokashi fermented fertilizer doses incorporated into the soil

With regard to height, the application of $200 \mathrm{~g} \mathrm{~m}^{-2}$ of bokashi resulted in the highest value, $23.7 \mathrm{~cm}$ (Figure 2). However, among the mean height values found in other studies with application of different doses, the maximum heights of arugula plants were $17.68 \mathrm{~cm}$ with organic cultivation (Linhares, 2008), and $23.88 \mathrm{~cm}$ with a dose of $200 \mathrm{~g} \mathrm{~m}^{-2}$ of bokashi (Fonseca, 2013). We can infer that the height varied within the maximum growth potential of the species.

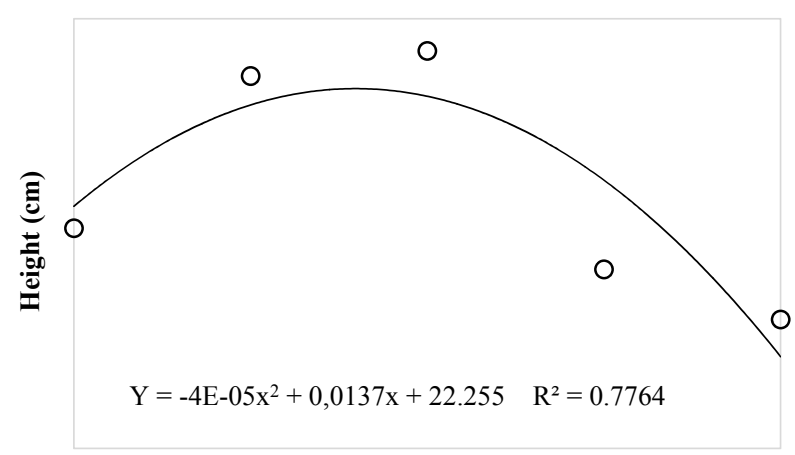

Bokashi doses $\left(\mathrm{g} \mathrm{m}^{-2}\right)$

Figure 2. Arugula plants' height as a result of bokashi fermented fertilizer incorporated into the soil

With respect to the variables relating to aboveground fresh and dry biomass, the best results were found with the fermented compost dose of $300 \mathrm{~g} \mathrm{~m}^{-2}$, exhibiting, on average, 23.9 and $22.1 \mathrm{~g}$ per plant, respectively (Figure 3). The increase provided by this kind of management was of $23.4 \%$ for fresh biomass and $52.2 \%$ for dry biomass, when compared with the treatment without fertilization. Sediyama et al. (2016) found a similar result in a research conducted with organic composts, where there was a biomass increase in lettuce, which was mainly due to the high supply of $\mathrm{N}$ found in diverse types of organic fertilizers, since this nutrient plays a function in the plant vegetative development. 

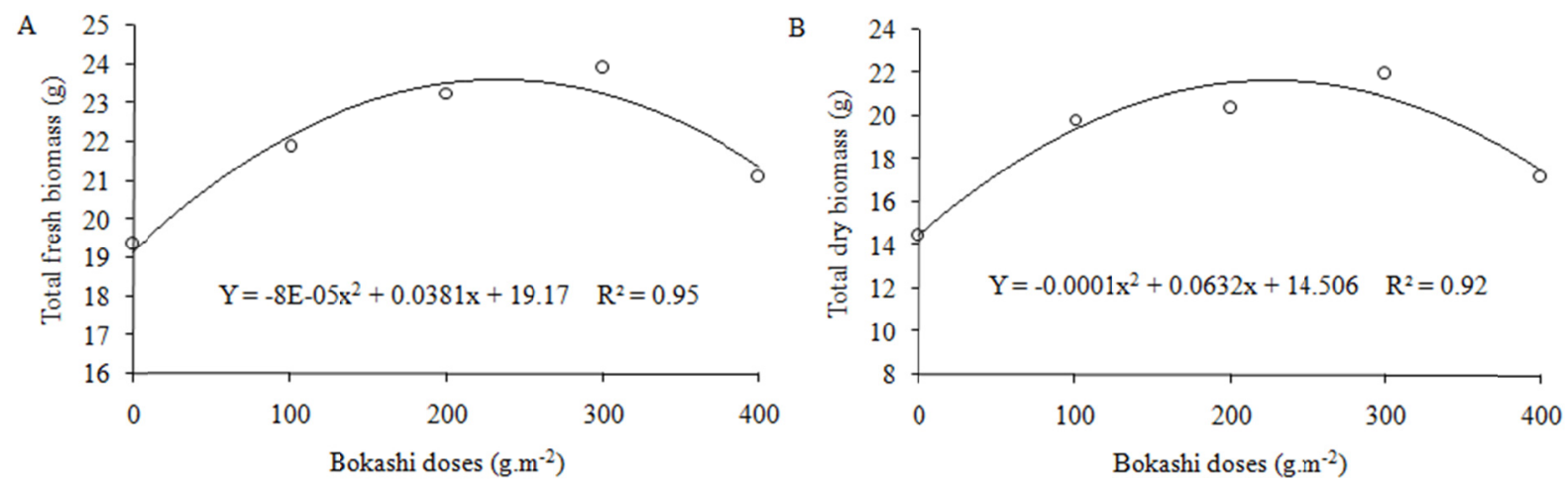

Figure 3. Fresh biomass (A) and dry biomass (B) of aboveground parts of arugula plants as a result of doses of bokashi fermented fertilizer incorporated into the solo

The dose of $200 \mathrm{~g} \mathrm{~m}^{-2}$ of bokashi resulted in $24.7 \mathrm{~g}$ of fresh root biomass, which represents an increase of $30.8 \%$ compared to the treatment without fertilization. The dose of $300 \mathrm{~g} \mathrm{~m}^{-2}$ exhibited, on average, $7.9 \mathrm{~g}$ of dry root biomass, representing an increase of $46.2 \%$ compared to the treatment without fertilization (Figure 4), which highlights the role of fermented fertilizer in root increment and, consequently, in plant development.
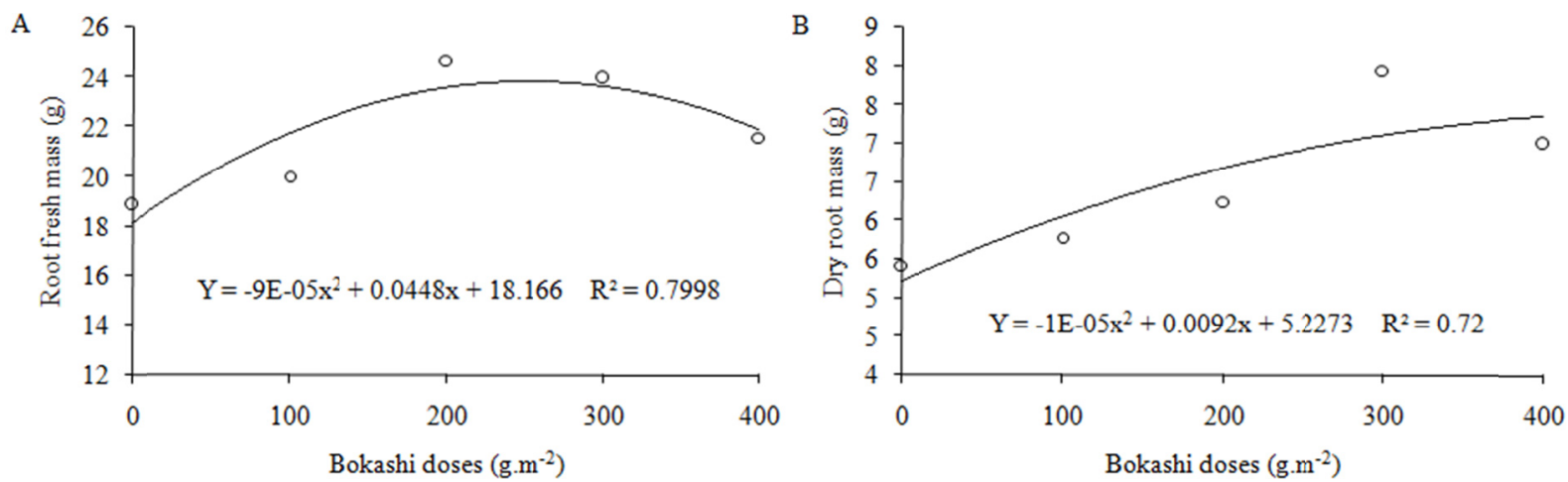

Figure 4. Fresh biomass (A) and dry biomass (B) of arugula roots as a result of doses of bokashi fermented fertilizer incorporated into the soil

The results found in the present work for arugula culture, where the highest doses of organic fertilizer were 200 $\mathrm{g} \mathrm{m}^{-2}$ for the parameters height and fresh root biomass, and $300 \mathrm{~g} \mathrm{~m}^{-2}$ for the number of leaves, aboveground fresh and dry biomass and dry root biomass are different from the cabbage culture, where the bokashi dose of $400 \mathrm{~g} \mathrm{~m}^{-2}$ resulted in higher fresh plant biomass and in fresh and dry root biomass (Condé et al., 2017).

It is important to emphasize that because it is a leafy vegetable, the number of leaves and aboveground fresh and dry biomass are the parameters that have the highest influence on the final price of sale of arugula. For this reason, the $300 \mathrm{~g} \mathrm{~m}^{-2}$ dose, which raised these values, is the most recommended for this culture. It is still worth mentioning that to the final price of sale of this product, an additional $30 \%$ is considered for vegetables cultivated in organic systems (CONAB, 2017). Thus, the use of bokashi-type fermented compost is recommended for arugula cultivation, in substitution of chemical fertilizers.

\section{Conclusion}

The use of bokashi-type fermented compost increased arugula yield with a dose of $300 \mathrm{~g} \mathrm{~m}^{-2}\left(3 \mathrm{t} \mathrm{ha}^{-1)}\right.$, resulting in an increase of $14 \%$ in the number of leaves, each plant exhibiting an average number of nine leaves, and an increase of $23.4 \%$ and $52.2 \%$ of aboveground fresh and dry biomass, respectively.

It is concluded that fermented compost is a promising resource to enhance plant growth, being a technology that can be easily produced and used. Thus, it is an alternative source for a good quality fertilizer for arugula cultivation. 


\section{Acknowledgements}

This study was financed in part by the Coordenação de Aperfeiçoamento de Pessoal de Nível Superior - Brasil (CAPES) and published with the financed support of the Programa de Apoio à Publicação de Artigos Científicos of the Fundação de Amparo à Pesquisa do Estado do Amazonas (PAPAC/FAPEAM).

\section{References}

Andreani Junior, R., Rocha, A. H. da S., \& Kozusny-Andreani, D. I. (2016). Viabilidade agronômica das culturas de rúcula e de almeirão em sistema de cultivo solteiro e consorciado. Nucleus, 13(1). https://doi.org/ $10.3738 / 1982.2278 .1568$

Brasil. (2014). Manual de métodos analíticos oficiais para fertilizantes minerais, orgânicos, organominerais e corretivos (p. 220). Brasília: MAPA/SDA/CGAL-Ministério da Agricultura, Pecuária e Abastecimento; Secretaria de Defesa Agropecuária; Coordenação-Geral de Apoio Laboratorial.

Carvalho, P. A. de, Barros, V. M. de S., Figueiredo, N. O., Barros, M.V. dos S., \& Ferreira, F. M. C. (2018). Desempenho agronômico de rúcula (Eruca sativa) em função do uso de microrganismos eficientes (EM) e de palhada. Cadernos de Agroecologia, 13(1). Retrieved from http://cadernos.aba-agroecologia.org.br/ index.php/cadernos/article/download/126 3/1465

CONAB (Companhia Nacional de Abastecimento). (2017). Tabela de preço de referencia do PAA-SUREG/AM. Retrieved from http://consultaweb.conab.gov.br/consultas/consultaprecopaa .do?method=consultar

Condé, V. F., Oliveira, D. N. F. de, \& Oliveira, J. E. Z de. (2017). Incidência e severidade de hérnia das crucíferas em repolho Brassica oleracea L. var. capitata) em solo tratado com biofertilizante tipo Bokashi. Ciência e Natura, 39(1), 7-15. https://doi.org/10.5902/2179460X21445

EMBRAPA. (1997). Manual de métodos de análise de solo (2nd ed.). Rio de Janeiro, RJ: EMBRAPA-SPI.

EMBRAPA. (2006). Sistema brasileiro de classificação de solos (2nd ed.). Rio de Janeiro, RJ: EMBRAPA-SPI.

Ferreira, A. K. da C., Dias, N. da S., Sousa Junior, F. S. de, Ferreira, D. A. da C., Fernandes, C. dos S., Lucas, L. E. F., ... Sá, F. V. da S. (2018). Physicochemical and Microbiological Properties and Humic Substances of Composts Produced with Food Residues. Journal of Agricultural Science, 10(1). https://doi.org/10.5539/ jas.v10n1p180

Ferreira, D. F. (2014). Sisvar: a Guide for its Bootstrap procedures in multiple comparisons. Ciência e Agrotecnologia, 38(2), 109-112, 2014. https://doi.org/10.1590/S1413-70542014000200001

Fonseca, J. O. G. da. (2013). Desempenho agronômico de alface e rúcula em função de doses de composto fermentado em condições de cultivo protegido, sob manejo orgânico em Nova Friburgo, RJ (Master's thesis, Universidade Federal Rural do Rio de Janeiro, Nova Friburgo, Brasil). Retrieved from http://cursos.ufrrj.br/ posgraduacao/ppgao/files/2016/04/Disserta\%C3\%A7\%C3\%A3o-Jovelina-OlgaGomes-da-Fonseca.pdf

Franco, G. G., Silva, S. L., Emiliano, E. D., Silva, M. V. S., \& Costa, F. dos S. (2018). Produção Agroecológica de Compostagem de Folhas, Frutos e Madeira Triturada. Cadernos de Agroecologia, 13(2). Retrieved from http://cadernos.aba-agroecologia.org.br/index.php/cader nos/article/view/2326

Gusmão, S. A. L., Lopes, P. R. de A., Silvestre, W. V. D., Oliveira Neto, C. F. de, Pegado, D. S., Silva, C. L. da S., ... Ferreira, S. G. (2003). Cultivo de rúcula nas condições do trópico úmido em Belém. Horticultura Brasileira, 21(2). Retrieved from http://www.abhorticultura.com.br/biblioteca/arquivos/Download/Biblio teca/olfg4031c.pdf

Linhares, P. C. F. (2008). Produção de rúcula em função de diferentes quantidades e tempos de decomposição de jitirana (Master's thesis, Universidade Federal Rural do Semi-Árido, Mossoró, Brasil). Retrived from http://www2.ufersa.edu.br/portal/view/uploads/setores/82/DissertacaoPAULO.pdf

Magrini, F. E., Camatti-Sartori, V., Finkler, R., Torves, J., \& Venturin, L. (2011). Características químicas e avaliação microbiológica de diferentes fases de maturação do biofertilizante Bokashi. Revista Agrarian, 4(12). Retrieved from http://ojs.ufgd.edu.br/index.php/agrarian/arti cle/view/1136

Mahmoud, A. W. M., \& Taha, S. (2018). Main sulphur content in essential oil of Eruca sativa as affected by nano iron and nano zinc mixed with or ganic manure. Agriculture, 64(2), 65-79. https://doi.org/10.2478/agri2018-0007

Menin, L. F., Rambo, J. R., Frasson, D. B., Pereira, T. A. X., \& Santi, A. (2014). Influência das fases lunares no desenvolvimento das culturas de rúcula (Eruca sativa Hill) e rabanete (Raphanus sativus L.). Revista 
Brasileira de Agroecologia, 9(3), 117-123. Retrieved from http://revistas.aba-agroecologia.org.br/index. php/rbagroecologia/article/view/15494/10667

Primavesi, A. (2002). Manejo ecológico do solo: A agricultura em regiões tropicais. São Paulo: Nobel.

Restrepo, J. R. (2014). Curso teórico-prático do ABC da agricultura orgânica: Remineralização e Recuperação da saúde dos solos; Microbiologia dos solos e técnica de cromatografia de Pfeiffer. Santa Catarina, BR: Atalanta. Retrieved from http://www.saude.pr.gov.br/arquivos/File/Manual_AgriCULTURA_ORGANICA_ Jairo_Restrepo_Rivera.pdf

Ribeiro, J. E. L. S., Vicentini, A., Sothers, C., Costa, M. A. da S., Brito, J. M. de, Souza, M. A. D. de, ... Procopio, L. C. (1999). Flora da Reserva Ducke: guia de identificação das plantas vasculares de uma floresta de terra-firme na Amazônia Central. Manaus, AM: INPA.

SBCS (Sociedade Brasileira de Ciência do Solo). (2010). O agronegócio e os fertilizantes. Boletim informativo da Sociedade Brasileira de Ciência do Solo, 35.

Sediyama, M. A. N., Magalhães, I. de P. B., Vidigal, S. M., Pinto, C. L. de O., Cardoso, D. S. C. P., Fonseca, M. C. M. F., \& Carvalho, I. P. L. de. (2016). Uso de fertilizantes orgânicos no cultivo de alface americana (Lactuca sativa L.) 'kaiser'. Revista Brasileira de Agropecuária Sustentável, 6(2), 66-74. https://doi.org/ 10.21206/rbas.v6i2.308

Soares, M. M., Bardiviesso, D. M., Barbosa, W. F. S., \& Barcelos, M. N. (2017). Adubação de cobertura com enxofre na cultura da rúcula. Revista de Agricultura Neotropical, 4(1), 49-52. https://doi.org/10.32404/ rean.v4i1.1171

Souza, J. L., \& Resende, P. (2003). Manual de horticultura orgânica. Viçosa, MG: Aprenda Fácil.

Tosta, D. S., Silva, M. W., Espinoso, S. Q., Costa, A. C., \& Lima, W. L. (2016). Uso de composto orgânico na produção de mudas de rúcula (Eruca sativa). Cadernos de Agroecologia, 11(2). Retrived from http://revistas.aba-agroecologia.org.br/index.php/cad/article/view/21097/13972

Trani, P. E., Fornasier, J. B., \& Lisbão. R. S. (1992). Cultura da rúcula. Campinas, BR: Instituto Agronômico. Retrieved from http://citeseerx.ist.psu.edu/view doc/download?doi=10.1.1.486.8085\&rep=rep $1 \&$ type $=$ pdf

Veloso, C. A. da C., Viégas, I. de J. M., Oliveira, R. F. de, \& Botelho, S. M. (2006). Amostragem de solo e planta para análise química. Belém, PA: Embrapa Amazônia Oriental.

\section{Copyrights}

Copyright for this article is retained by the author(s), with first publication rights granted to the journal.

This is an open-access article distributed under the terms and conditions of the Creative Commons Attribution license (http://creativecommons.org/licenses/by/4.0/). 